\title{
АПОЗИТИВНА СИНТАКСЕМА ЯК ВИРАЗНИК ТРОПЕЇЧНИХ ЗНАЧЕНЬ У ХУДОЖНЬОМУ ТЕКСТІ
}

\author{
ІРИНА РАБЧУК
}

Національний університет „Острозька академія”, Острог -Україна

iryna.rabchuk@oa.edu.ua; ORCID: 0000-0003-2865-4551

\section{APOZYTYWNY SYNTAKSEM JAKO REPREZENTANT ZNACZEŃ TROPICZNYCH W TEKŚCIE LITERACKIM}

\author{
IRYNA RABCZUK \\ Uniwersytet Narodowy „Akademia Ostrogska”, Ostróg — Ukraina
}

\begin{abstract}
STRESZCZENIE. Autorka artykułu skupia uwagę na funkcjonowaniu apozytywnych epitetów składniowych i metafor w poetyckiej różnorodności artystycznego stylu wypowiedzi. W niniejszym badaniu podjęto próbę całościowej analizy spektrum tropicznych znaczeń pozytywnej i półpredykatywnej składni w prozie i w poetyckich tekstach literackich charakteryzujących się pewnym obciążeniem stylistycznym. Często apozytywy funkcjonują jako epitety, porównania i metafory. Możemy też zauważyć, że w tekście literackim apozytywny syntaksem zarówno w pozycji izolowanej, jak i nieprzydzielonej można wyrazić za pomocą personifikacji, oksymoronu, paronomii, antytezy, amplifikacji. Potrafi także działać jako wyraz ironii, sarkazmu. Zdarzały się przypadki zastosowania półprzewidywalnego apozytywnego syntaksemu synekdochy, peryfrazy i hiperboli. W rezultacie badania stwierdza się, że wszystkie apozytywy o funkcji tropicznej przyczyniają się do tworzenia wyrazistych obrazów zarówno ludzi, jak i innych istot, przedmiotów, otaczających ich zjawisk, pozwalają pisarzom przekazywać w wystarczająco angażujący i skondensowany sposób myśli, postawy i osobliwości światopoglądu.
\end{abstract}

Słowa kluczowe: syntaksem apozytywny, półpredykatywny syntaksem apozytywny, styl artystyczny, trop, stylistyczne nacechowanie syntaksemu pozytywnego. 


\title{
APPOSITIVE SYNTAXEME AS AN EXPRESSION OF TROPICAL MEANINGS IN BELLES-LETTERS TEXT
}

\author{
IRYNA RABCHUK \\ National University of „Ostroh Academy”, Ostroh — Ukraine
}

\begin{abstract}
The article focuses on the fact that modern Ukrainian linguistic research is mainly devoted to the functioning of appositive epithets and metaphors syntaxemes in the poetical type of the belles-letters style. Therefore, the aim of the paper is an attempt at a comprehensive analysis of the tropical meanings of the appositive syntaxeme proper and semi-predicative appositive syntaxeme in texts of in prose and poetical belles-letters style, as well as a description of their stylistic roles. The article reveals that, in most cases, appositive syntaxemes are epithets, similes, and metaphors. It has been found that in belles-letters text, the appositive syntaxeme in detached and non-detached positions can take the form of the following tropes: personification, oxymoron, paronomasia, antithesis, amplification. Moreover, it is capable of expressing irony and sarcasm. The author records the cases of the use of semi-predicative appositive syntaxemes in the roles of synecdoches, periphrases and hyperboles. The author concludes that all appositive syntaxemes with tropical function create bright images of human characters as well as the other creatures, objects and phenomena that surround them. They allow writers to convey their thoughts, attitudes, and the peculiarities of their perception of the world.
\end{abstract}

Keywords: appositive syntaxeme proper, semi-predicative appositive syntaxeme, belles-letters style, trope, stylistic role of appositive syntaxeme.

позитивна синтаксема, або ж апозитивема, функціює в усіх сти-
лях сучасної української літературної мови. Як слушно зауважує
О. Остроушко, ії стилістичне значення характеризується оцінністю, емоційністю та експресією [Остроушко 2011: 393], які найповніше можуть бути втілені саме в художньому стилі мовлення. У поєднанні з означуваним словом апозитивема стає засобом творення яскравих образів осіб, предметів та явищ, дозволяє письменникам у досить стислій, влучній і конденсованій формі передати думки, ставлення, особливості світовідчуття. Специфіка стилістичного навантаження апозитивної синтаксеми в тексті художнього стилю значною мірою зумовлена вибором тропа, роль якого вона виконуватиме у відокремленій чи невідокремленій позиції.

Сучасні українські лінгвостилістичні дослідження здебільшого присвячені функціюванню апозитивних синтаксем-епітетів і метафор у поетичному різновиді художнього стилю мовлення. Так, В. Філінюк вивчає епітети-прикладки в поетичній мові Е. Андієвської [Філінюк 2004: 92-95], Л. Підкамінна - у поетичній мовотворчості Т. Шевченка [Підкамінна 2007: 241-246], а I. Данилюк на матеріалі українського поетичного дискурсу досліджує апо- 
зитивеми-маринізми у тропеїчній функції епітетів і метафор [Данилюк 2011: 119-123]. Метафоричне значення апозитивних синтаксем стало об'єктом наукових розвідок Н. Слободи [Слобода 2011: 226-229] та Л. Костич, яка також описала апозитивеми-перифрази й ампліфіковані апозитивні синтаксеми в поезіях Т. Шевченка [Костич 2011: 225-233]. О. Марчук дослідила структуру апозитивем-порівнянь у творах М. Коцюбинського [Марчук 2006: 212-218]. На окремі зауваги щодо функціювання апозитивних синтаксем, що стають носіями саркастичного чи іронічного значення в поетичному тексті, натрапляємо в статтях Г. Козачук [Козачук 2014: 101-102] та О. Остроушко, яка ще й зазначає, що апозитивема здатна надавати мовленню колориту інтимізації [Остроушко 2011: 393-394].

Л. Мацько в Стилістищі украӥнської мови (2003), аналізуючи типи епітетів, окремо виділяє виражені іменником-прикладкою. Науковиця зазначає, що в основі їхнього формування перебувають асоціативні зв'язки подібності за якоюсь (переважно зовнішньою) ознакою, а також фоновий матеріал українознавства, знаки фольклору й національної культури [Мацько, Сидоренко, Мацько 2003: 354-355]. О. Яцук зауважує, що найпоширенішим тропом, який інтенсифікує напівпредикативні апозитивні синтаксеми в художніх текстах межі XX-XXI ст., $є$ метафора різноманітних типів, зокрема, порівняння, алегорія, символ, уособлення, персоніфікація та метонімія, представлена перифразом [Яцук 2012: 194]. Також дослідниця аналізує засоби художньо-образної функції напівпредикативних апозитивних синтаксем у єдності їхньої тропеїчної функції, лексичних, словотвірних та морфологічних засобів вираження [Яцук 2012: 195-199].

Огляд літератури засвідчує, що спектр тропеїчних значень апозитивної синтаксеми в невідокремленій і відокремленій позиціях залишається вивченим не комплексно, а увага мовознавців здебільшого прикута до функціювання її в поетичних текстах. Мета пропонованого дослідження - з'ясувати, якими тропами може бути виражена апозитивема як у прозових, так і в поетичних текстах художнього стилю, а також відповідно до цього схарактеризувати її стилістичне навантаження.

Як засвідчують наші спостереження, а також невипадковий інтерес вищевказаних дослідників до "вибіркових" тропів, українські письменники в художніх текстах найчастіше вдаються до апозитивних синтаксем-епітетів, порівнянь та метафор. Л. Підкамінна слушно зауважує, що апозитивема-епітет функціює як економна, семантично глибока й експресивна форма характеристики-оцінки [Підкамінна 2007: 245], яка може стосуватися як героїв-осіб, так й інших істот, предметів, явищ, що їх оточують, напр.: ..ивіркуни сюркотять кулеметами / і тримає артобстріл гроза / ескадрильї птахів-безсмертників / креслять в небі сигнальні знаки... [Іздрик 2018]; ... иудо-дитя зупинялося, усміхалося обидвом зразу - $i$ з вереском бігло, шпортаючись, до мами 
[Матіос 2011: 126]; ...котрий так необачно відважився дістатися на автомобілі аж до Кременчука - непоказного містечка, якому, мабуть, ніколи й не снилося, щуо воно стане губернським містом... [Шкляр 2010: 25]. Також епітети широко вживані при апозитивемах-вокативах. У цій позиції вони не лише уточнюють зміст означуваного слова, але й характеризують його, тобто виражають позитивне чи негативне ставлення до реального чи абстрактного адресата. Позитивна характеристика пов'язана з почуттями любові, турботи, ніжності, світлих надій, напр.: Але ви, срібний Михайлику, без пояса дрова кололи, а вітер був великий, можете поперек застудити [Матіос 2011: 81]; A ти, сестро моя найдорожча, Марусенько моя золота! [Шкляр 2010: 314]; Нi, не купить за гроші /щастя, немов вина. /Юність моя хороша, / де ж ти, моя весна? [Симоненко 2012: 75]. Негативна характеристика асоціюється зі зневажливим чи іронічним ставленням, викривальним змістом висловлювання, напр.: «Гріх тобі, старий гріховоднику, ой, гріх», - сказав собі Яків [Лис 2010: 185]; ПОЛІНО, ЯК МЕНІ ОСТОЧОРТІЛИ / Ви, найдешевша моя скорбото [„Бу-Ба-Бу” 2008: 333].

Як зазначає О. Межов, у художніх текстах апозитивні синтаксеми нерідко виражають порівняльну семантику, виконуючи роль об'єктів порівняння, а назви осіб чи предметів, виражені означуваним словом, стають суб'єктами порівняння, адже їх обох об'єднують якісь спільні ознаки [Межов 2012: 318]. Отже, порівняльне значення між означуваним словом й апозитивемою може грунтуватися на: 1) основі зовнішньої схожості: Як простирадло, бгається в складки Земля. / Спить на ній хлопчик - важке золоте джмеля... [Забужко 2019]; Адельию! - перебила ї̈ бабуся-суничка [Винничук 2019]; Бачиш? дерев розхристані жсар-серия / зливи-коралі вдягають - тобі на втіху [Жіноче коло 2020]; Сотні червоних риб / у місті-акваріумі / шушукаються про Валентина [Жіноче коло 2020]; 2) поведінкової подібності: Господи, з яким виразом на обличчі ступала до їхньої вбогої оселі гостя-пава [Лис 2010: 106]; ...щеоб в ополонку суму, як у хвилястий Світязь, / їи припливали весни, вбрані, як баронеси, / [...] чорні кармен-торнадо в таниях катастрофічних... [Жіноче коло 2020] тощо. Для таких конструкцій характерна співвіднесеність із підрядними неповними порівняльними частинами [Межов 2012: 319], напр.: Спить на землі хлопчик, як важке золоте джмеля; Ї̈̈ перебила бабуся, немов суничка; Сотні червоних риб у місті, наче акваріумі, шушукаються про Валентина; До неї припливали чорні кармен, ніби торнадо, в таниях катастрофічних. Апозитивні синтаксеми-порівняння увиразнюють, конкретизують уявлення про певний художній образ.

Досить поширене використання в художньому стилі мовлення апозитивем-метафор, які додають будь-якому образу об'єму, своєрідної двовимірності. Їхнє метафоричне значення виникає на основі: 1) схожості форми, кольору, зовнішнього вигляду предметів, явищ (Що бачить це холодне око, / 
світило металеве?.. [„Бу-Ба-Бу” 2008: 313]; Десь на горизонті хмара-хустка / Манить вдаль, мов дівчина у сад... [Симоненко 2012: 121]; ... де батько завжди купував йому маківники, золотисті медяники-коники й довгі м'ятні «кумхвети»... [Шкляр 2010: 39]); 2) подібності якихось властивостей предметів, явищ (Мені з тобою море по коліна / $і$ ні по чому каторжні труди, / Моя вкрайнська мово солов '̈̈на -/ Джсерельний струмінь свіжсої води [Симоненко 2012: 121]; Бо Львів - ие насправді корабель-привид [„Бу-Ба-Бу” 2008: 128]; Вийду з палатки, у темінь пірну, / Думкою-мрією в Київ майну [Симоненко 2012: 77]); 3) близькості емоційних вражень людини від когось, чогось (Cnaсибі тобі, моя золота [Шкляр 2010: 314]) тощо. У текстах художнього стилю натрапляємо на апозитивні синтаксеми, які в складі апозитивного словосполучення стають актуалізатором такого різновиду метафори як персоніфікація: Та літо чується вже кожному безсилим, / I, заблукавши в хащі лісові, / Свої багатства осені-вдові / Передає безпечно і невміло [Симоненко 2012: 130]; Ті роки віддаляються помалу. / Будинок наш був близько від вокзалу, / а там - надсадні чорні роботяги - / вночі гули незримі паротяги [Андрухович 2019]; ... але тепер то вже було місто переможене, впокорене і полонене, місто-невільник... [Винничук 2019]; Так, як живе стіна / церкви колишньоїв шепоті динамітнім / квітів-прибульців з інакших сумних планет [Жіноче коло 2020]. Цей троп „конкретизує образ, уявно робить його доступним для сприймання кількома аналізаторами: візуальним, акустичним, тактильним тощо" [Мацько, Сидоренко, Мацько 2003: 378], таке одухотворення явищ, предметів, абстрактних понять створює ефект об'ємного образу, що захоплює увагу читача, і ніби припускає існування паралельних світів із тим, у якому перебувають і діють персонажі чи ліричні герої.

Апозитивема може стати джерелом творення синекдохи й позначати особу частиною iї одягу (Ах панунцю Катрусю - / капелюшик з широкими криcaмu! [Забужко 2019]) чи частиною тіла, яка в конкретній ситуації видається найістотнішою (Ось тобі, вбога пуста голова, / перше знамення Різдва - / снігу добув ти для білих поем, / вітру черпнувши плащем [„Бу-Ба-Бу” 2008: 86]), тощо. Також апозитивна синтаксема, даючи іншу, образну назву, що вказує на суміжні з означуваним предметом, явищем чи абстрактним поняттям ознаки, виконує стилістичну функцію перифраза: Цвинтар - місто мертвих - версія міста живих, яке перейшло в небуття [„Бу-Ба-Бу” 2008: 376]; Я з тих домів, що мітила Чума — / Вельможна пані у кибалці білій, / Нічним повозом їдучи крізь місто... [Забужко 2019]; Прощяавайте, всі! і ти, круглолиций, / що згори, як манну, даруєш укази [Андрухович 2019]; $і$ головне - ие присутність иієї / різнодихаючої, полімовної істоти - моря, / великого ритмотворця, $i$, до певної міри, картинної / галереї, / $i$, можливо, театру, у якому - глядач я? актор я? [„Бу-Ба-Бу” 2008: 335]. В останньому прикладі бачимо своєрідне кільцеве нагромадження апозитивем: апозитивна 
синтаксема 'моря' залежить від поширеного означуваного словосполучення 'цієї різнодихаючої, полімовної істоти' і водночас сама є означуваним словом до однорідних апозитивем 'великого ритмотворця', ‘картинної галереї', ‘театру’. Виразність перифраза полягає в тому, що, з одного боку, в його художній структурі завжди є елемент загадки, адже читачеві доводиться відгадувати, щоб зрозуміти, про що саме йдеться в перифразі, а з іншого боку - елемент словесного прикрашання описуваного предмета, явища чи поняття [Галич, Назарець, Васильєв 2008: 219].

Досить часто в текстах художнього стилю використовують засоби, здатні передати читачеві специфіку стосунків героїв, їхнє ставлення одне до одного, позицію щодо певних подій, явищ. Ефективним інструментом у випадках, коли потрібно зобразити складність взаємин, приховане глузування, стає апозитивема-іронія (А ви щзо, любко-душко, хотіли їм свічку світити, чи показувати, коли ся діти роблять?! [Матіос 2011: 94]; Ти все ще докучаєш своїми запитаннями, ангеле мій? - скуйовдив йому білого чуба новопідсілий Хома [„Бу-Ба-Бу” 2008: 163]; Ця кобіта - навпроти: помилено долею ряд / Це могла б бути я. Коли б вийшла за тебе, мій милий [Забужко 2019]), а коли слід передати зневажливо-викривальне, уїдливе ставлення до когось чи до чогось, - апозитивема-сарказм (Мос хворе століття, мос голомозе століття! / Як безгучно і швидко тебе до шпиталю внесуть!.. [Забужко 2019]; С міста-ренегати, є просто байстрята, / С леви, що мурликають, наче коти, —/ Божевільно байдуже облизують трати / і пишаються з власної сліпоти [Симоненко 2012: 244]; Вони, новітні наполеонцики, переконані, що Україна - ие вони [„,Бу-Ба-Бу” 2008: 360]).

До гіперболізації зображуваного через використання апозитивних синтаксем вдаються з метою підкреслення особливо ніжного, співчутливого ставлення одного персонажа до іншого, зображення їхньої глибокої душевної прив'язаності: Хіба йому, такому перемерзлому, такому перетрудженому на своєму віку, зігрітися лише травою чи землею? [Матіос 2011: 26]. Також на гіперболізовані апозитивеми можуть нашаровуватися елементи аксіологічного значення: пафосно-позитивного (...он уже чути, як шумить Річка, найчистіша вода в Свропі, жодного виробництва на берегах, підношуся чимраз вище, коли звідси озирнутися на Чортопіль... [„„Бу-Ба-Бу” 2008: 184]; Самійло (Самуель) Немирич, цей недоречно забутий $і$ завчасно згаслий пагінчик на дереві нашого національного бандитизму, привертає до себе увагу насамперед стилістично [„Бу-Ба-Бу” 2008: 141]) чи пафосно-іронічного (Всемогутній Базю, боже інформації! [„Бу-Ба-Бу” 2008: 110]).

Дуже виразний стилістичний прийомом - використання в художньому тексті апозитивеми-оксиморона, яка створює ефект смислового парадоксу, адже за мінімальної кількості мовленнєвих засобів розкривається вся складність, суперечливість описуваного персонажа, явища, предмета чи ситуації 
[Галич, Назарець, Васильєв 2008: 237], напр.: Вона, ця панянка і ильондра в одній особі, ніби насміхалася й водночас ї̈ слова казали про щось інше, йому не підвладне [Лис 2010: 78]; Любов-війна [Іздрик 2018]; Наче вчора бігав я до школи / i садив ті вишеньки малі, / А тепер гудуть над ними бджоли / і поважні пустуни-джмелі [Симоненко 2012: 89].

Цікавий стилістичний ефект засвідчує використання апозитивної синтаксеми для створення парономазії, адже, на думку Л. Мацько, ідея звукового зближення апозитивеми й означуваного слова поширюється на їхню семантику й веде до смислового зближення [Мацько, Сидоренко, Мацько 2003: 376]. Отож, автор може досягнути викривального ефекту (Te, чого не треба, иі люди-юди видять і знають... [Матіос 2011: 115]) або, вдаючись до римування, підкреслити позитивно-іронічне ставлення до свого персонажа (Та сама компанія - Грищь і Немирич, і ловелас Хомський, гомський, зі своїми претензіями, ті самі жарти, ті самі вірші... [„„Бу-Ба-Бу” 2008: 152]). Також натрапляємо на випадки звукосемантичного зближення не в межах апозитивного словосполучення, а уподібнення власне апозитивної синтаксеми й суб'єктно-атрибутивної чи об' єктної, напр.: Песій Ринок вітав мене песім гавкотом [„Бу-Ба-Бу” 2008: 96]; А мати-сиротина / римується із тином, / а на тім тині Мина / сидить і награє / на банджо жовто-синім... [Забужко 2019]. Цей своєрідний вихід у контекст створює письменнику широке поле для загравання з читачем, нашаровування змістів, передачі іронічних, сатиричних тощо тональностей.

Неординарним прийомом уважаємо використання апозитивеми-антитези, яка творить надзвичайно контрастні й динамічні образи, напр.: залізна логіка психозу / виводить нас на чисті води / у голий біль на білу волю / де пальми-сосни сніг-пісок [Іздрик 2018]. Такі химерні апозитивні словосполучення наштовхують читача на широту сприйняття, як інтелектуальну, так і географічну, а подальші рядки спонукають вбачати в апозитивемах-антитезах втілення алогічності, хаотичності світу й зміну полюсів: промінчик божого психозу / така любов - така краса / i от уже - під снігом пальми / $і$ сосни випалені сонцем... [Іздрик 2018]. Не менш цікавий приклад: Хвойдо русява у світлому плащику, / Светрик під горло застебнеш на защіпку. / Віри иеей мережу. Душу морожу. / Я вже без тебе жити не можу [„Бу-Ба-Бу” 2008: 241]. У ньому напівпредикативна апозитивна синтаксема дистанційована від означуваного слова 'без тебе', а антитези 'хвойда — кохана', 'хвойда - застебнутий светрик під горло’ можна зчитати лише на рівні строфи, адже саме в контекстному оточенні апозитивема знаходить своє семантико-стилістичне розшифрування [Підкамінна 2007: 244].

Яскравим синтаксичним засобом увиразнення художнього мовлення стає використання ампліфікованих апозитивних синтаксем. Зумисне "нанизані" апозитивеми, будучи виразниками тропеїчного значення, виконують ще й ха- 
рактеризувальну (за родинними стосунками, вдачею, поведінкою, місцем проживання, зовнішнім виглядом, освітнім статусом, подібністю осіб з іншими особами, предметами чи явищами тощо; за призначенням предметів, явищ, їхньою зовнішньою, внутрішньою чи асоціативною подібністю з іншими предметами, явищами тощо) та аксіологічну функцію (виразник негативно-викривального, зневажливого, іронічного, оцінно-описового, пафосно-позитивного тощо значення) щодо персонажів чи предметів, явищ, описаних у художньому тексті: Ти, мерзо мерзенна, приймаку дурний, безродне насіння, ти, дурню остатний, щуо до такої самої дурної пристав, ти, злодію галіцейський, паськудо паськудна... я на тебе управу знайду, щуе не вродився такий, щзоби я на нього управи не знайшла... [Матіос 2011: 49]; ... ти ж бо красунчик, певно, студентик, не масш місия, бідацтво, стойи у проході, нудишся, то й розглядаєш заміжніх жінок, юний Дон Жуан, перелесник, тростиночка, суцільна флейта, мабуть, з комсомолу вийшов, записався у СНУМ чи щуе куди, он і червоно-чорний значок на місці, а зачіска, як у Девіда Боуї, початкуючий плейбойчик, таке воно ніжне, мабуть, і голиться не частіше, як раз на два тижні... [,„Б-Ба-Бу” 2008: 153]. Запропоновані приклади засвідчують, що напівпредикативні апозитивні синтаксеми можуть перебувати безпосередньо в постпозиції щодо означуваного слова, а також відриватися, дистанціюватися від нього. Така апозитивемна ампліфікація дозволяє авторові, уникаючи тавтологій, концентрувати максимальну кількість інформації про персонажа в одному складному багатокомпонентному реченні, яке, фактично, стає своєрідним словесно-емоційним портретом героя. Цікавим є прийом ампліфікації препозитивних апозитивем-порівнянь, що характеризують ліричного героя: Равлик без черепашки - / Тоненьке стебельце проросле на танкодромі / Немовля у візочку полишенім напризволяще - / Кроткий ідіот що до всіх усміхасться в людському тлумі - / Безногий серед дороги - / Жінка вночі на порожнній вулиці - / Зародок в лоні перед абортом - / Пелюсткова шкірка щцо плаче від дотику - /Око на світлі нічим крім сльози не прикрите - / Кожен із нас кожної миті цілком несвідомо - / Сплячий мужчина [Забужко 2019]. Динамізму, багатоплановості інтерпретацій додає, безумовно, постійне порівняння ліричного героя-чоловіка то з істотами-неособами, то з неістотами (елементами природи, частинами людського тіла), то з особами, зокрема, жіночої статі.

Натрапляємо й на випадки ампліфікації власне апозитивних синтаксем, які стають потужним стилістичним засобом, що характеризує узагальненого героя твору (людство) за зовнішньою, внутрішньою чи асоціативною подібністю з предметами чи явищами й надає йому іронічну оцінку: Обречевлений світ впорскуватиме в себе отруту вмирання, $і$ ми загинемо. Нам потрібно припинити неконтрольоване обречевлення, бо ми самі станемо речами. Вже майже стали. Людина-авто, людина-зброя, людина-крісло, людина-хата, 
людина-одяг, людина-комп'ютер, людина-телевізор, людина-радіохвиля, людина-плеєр, людина-торба, людина-гроші... Де наш людина-бог? [„Бу-Ба-Бу” 2008: 385].

Як власне апозитивна, так і напівпредикативна апозитивна синтаксема здатна набувати в художньому тексті емоційно-експресивного значення, яке „співвідноситься зі сферою емоційно-чуттєвого сприймання і закріплює стан мовця, його думки, почуття" [Остроушко 2011: 394]. Колорит інтимізації мовлення героїв досягається: 1) використанням іменників і субстантивованих прикметників зі зменшено-пестливими суфіксами -юн'-, -yc'-, -чик-, -еньк- тощо: ...Ви виділи, Михайлюню, вона хрестилася $і$ казала отченаш.. [Матіос 2011: 151]; ... ти не уявляєш собі, Мартусю, які вони молодиі... [„„БуБа-Бу” 2008: 202]; Синочку-голубчику, Богом тебе благаю, візьми ие дитя й заховай десь на хуторах у добрих людей... [Шкляр 2010: 184]; Ти, рідненька, не журися - / За грибами ж я піду [Симоненко 2012: 108]; 2) поєднанням епітетів / метафор / усталених етикетних формул й іменників зі зменшено-пестливими суфіксами -к-, -очк-, ус'- тощо: I, дай Боже, щэоби ти, солодка моя дитинко, ніколи не була такою Божою людиною, як Параска [Матіос 2011: 16]; Я більше хвилююся за Тіну, ти ж пам'ятаєш, товаришочку, Тіну, мою сірооку пташку, яка тепер так далеко... [Шкляр 2010: 338]; Катерино Михайлівно, панно Катрусю! [Забужко 2019]; 3) вживанням самостійних звертань, „пройнятих народнопісенною звучністю” [Дудик 2005: 270] (коханий, моя дорога, милий тощо) або в поєднанні з іменниками чи прикметниками в кличному відмінку: Що з тобою, кохана? [Лис 2010: 122]; Я $і$ ТАМ пам'ятатиму, як Ви, мій дорогий тату, витяглися в нитку, щоб дати мені освіту, і як тішилися, щзо колись із мене будуть люди [Шкляр 2010: 314]; ...ій дивився в оченьки ясні: / «Ой скажи мені, чому хмелію / Біля тебе, мила кароока?» [Симоненко 2012: 102]. У художньому тексті апозитивна синтаксема може стати виразником не лише теплих, інтимних стосунків героїв, але й фамільярних, напр.: $і$ ти теж, моя рибонько, - сказав Юрко і грайливо провів рукою їи по сідниці, але не отримав практично ніякого задоволення [,Бу-Ба-Бу” 2008: 195].

Отже, спектр тропеїчних значень власне апозитивної й напівпредикативної апозитивної синтаксем досить широкий, адже вони можуть функціювати в художньому тексті як епітети, порівняння, метафори, персоніфікації, оксиморони, парономазії, антитези, ампліфікації, виразники іронії, сарказму, а також емоційно-експресивних значень, зокрема, колориту інтимізації чи фамільярності мовлення. Також ми зафіксували випадки вживання напівпредикативних апозитивних синтаксем-синекдох, перифразів та гіпербол. Усі ці апозитивеми з тропеїчною функцією сприяють зануренню читача в світ художнього слова, змушують його співпереживати героям, створюють ефект реальності зображуваного. 


\section{Список використаної літератури}

Галич О., Назарець В., Васильєв Є., Теорія літератури, наук. ред. О. Галич, Київ: Либідь, 2008.

Данилюк I.В., Маринізми в образній структурі апозитивних словосполучень (на матеріалі украӥнського поетичного дискурсу), [в:] „Мова і культура”, гол. ред. Д. С. Бураго, Київ 2011, вип. 14, т. VIII (154), с. 119-123.

Дудик П.С., Стилістика украӥнської мови, ред. К. С. Мусієнко, Київ: Видавничий центр „Академія”, 2005.

Козачук Г.О., Апозитиви та сполучення слів апозитивного типу в „Кобзарі” Тараса Шевченка, [в:] „Науковий часопис НПУ ім. М. П. Драгоманова. Серія 10: Проблеми граматики і лексикології української мови”, відп. ред. М. Я. Плющ, Київ 2014, вип. 11, c. $99-103$.

Костич Л., Прикладкові конструкиії в поезіях Т. Шевченка, [в:] „Шевченкознавчі студії, гол. ред. Г. Ф. Семенюк, Київ 2011, вип. 13, с. 225-233.

Марчук О.І., Порівняльні функиї прикладки у творах М.М. Коцююбнського, [в:] „Записки з українського мовознавства”, відп. ред. О. І. Бондар, Одеса 2006, вип. 16, с. 212-218.

Мацько Л.І., Сидоренко О.М., Мацько О.М., Стилістика української мови, за ред. Л. І. Мацько, Київ: Вища школа, 2003.

Межов О.Г., Типологія мінімальних семантико-синтаксичних одиниць, Луцьк: ВНУ ім. Лесі Українки, 2012.

Остроушко О., Функиії прикладкових конструкиій у поетичному тексті (на матеріалі творів Л. Костенко, І. Драча), [в:] „Сучасні проблеми мовознавства та літературознавства", відп. ред. І. В. Сабадош, Ужгород 2011, вип. 16, с. 393-395.

Підкамінна Л.В., Апозитивні епітети у поетичній мовотворчості Т.Г. Шевченка, [в:] „Науковий часопис Національного педагогічного університету ім. М. П. Драгоманова. Серія 10: Проблеми граматики і лексикології української мови”, відп. ред. М. Я. Плющ, Київ, 2007, вип. 3, с. 241-246.

Слобода Н.В., Виокремлення як засіб експресивізації метафор (на матеріалі поезї шістдесятників), [в:] „Науковий часопис Національного педагогічного університету ім. М. П. Драгоманова. Серія 10: Проблеми граматики і лексикології української мови”, відп. ред. М. Я. Плющ, Київ 2011, вип. 7, с. 226-229.

Філінюк В.А., Eпітети-прикладки в поетичній мові Емми Андієвської, [в:] „Наукові записки Тернопільського національного педагогічного університету. Серія: Мовознавство”, гол. ред. Д. Г. Бучко, Тернопіль 2004, № 1 (11), с. 92-95.

Яцук О.В., Виражальні засоби реалізації художньо-образної функиії напівпредикативних апозитивних одиниць (на матеріалі української прози кіния XX-поч. XXI cm.), [в:] „Наукові праці Кам’янець-Подільського національного університету ім. Івана Огієнка. Філологічні науки”, відп. ред. Л. М. Марчук, Кам’янець-Подільський 2012, вип. 31, c. $193-199$. 


\section{Список використаних джерел}

Андрухович Ю., Листи в Украӥну. Вибрані вірші, [в:] Електронний ресурс: http://chtyvo. org.ua/authors/Andrukhovych/Lysty_v_Ukrainu_zbirka/ (20.12.2019).

„Бу-Ба-Бу” (Юрій Андрухович, Олександр Ірванецьь, Віктор Неборак): Вибрані твори, упоряд. В. Габор, Львів: ЛА „Піраміда”, 2008.

Винничук Ю., Танто смерті, [в:] Електронний ресурс: https://online-knigi.com/page/190964 (28.12.2019).

Жіноче коло, уклад. П. Городинська, [в:] Електронний ресурс: http://shron1.chtyvo.org.ua/ Horodyska_Polina/Zhinoche_kolo_zbirka.pdf (09.02.2020).

Забужко О., Друга спроба, [в:] Електронний ресурс: http://poetyka.uazone.net/zabuzhko/ (28.12.2019).

Іздрик Ю., Мертвий щзоденник, [в:] Електронний ресурс: http://izdryk-y.livejournal.com/ (10.09.2018).

Лис В., Століття Якова, Харків: Книжковий Клуб „Клуб Сімейного Дозвілля”, 2010.

Матіос М., Слодка Даруся, Львів: ЛА „ПІРАМІДА”, 2011.

Симоненко В., Вибрані твори, упор. А. Ткаченко, Д. Ткаченко, Київ: „Смолоскип”, 2012. Шкляр В., Залишенещь. Чорний Ворон, Харків: Книжковий Клуб „Клуб Сімейного Дозвілля”, 2010.

\section{Spysok wykorystanoi literatury [References]}

Halych O., Nazarets V., Vasyliev Ye., Teoriia literatury [Theory of Literature], nauk. red. O. Halych, Kyiv: Lybid', 2008.

Danyliuk I.V., Marynizmy v obraznii strukturi apozytyvnykh slovospoluchen (na materiali ukrainskoho poetychnoho dyskursu) [Marine Terms in Appositive Word Combinations (on the material of Ukrainian poetical discourse)], [v:] „Mova i kultura”, hol. red. D. S. Buraho, Kyiv 2011, vyp. 14, t. VIII (154), s. 119-123.

Dudyk P.S., Stylistyka ukrainskoi movy [Stylistics of Ukrainian Language], red. K. S. Musiienko, Kyiv: Vydavnychyi tsentr „Akademiia”, 2005.

Kozachuk H.O., Apozytyvy ta spoluchennia slivapozytyvnoho typu v „, Kobzari” Tarasa Shevchenka [Appositions and Joinings of Words of Appositive Type in Taras Shevchenko's „Kobzar”], [v:] „Naukovyi chasopys NPU im. M. P. Drahomanova. Seriia 10: Problemy hramatyky i leksykolohii ukrainskoi movy", vidp. red. M. Ya. Pliushch, Kyiv 2014, vyp. 11, s. 99-103. Kostych L., Prykladkovi konstruktsii v poeziiakh T. Shevchenka [Appositive Constructions in T. Shevchenko's Poetry], [v:] „Shevchenkoznavchi studii”, hol. red. H. F. Semeniuk, Kyiv 2011, vyp. 13, s. 225-233.

Marchuk O.I., Porivnialni funktsii prykladky u tvorakh M. M. Kotsiubynskoho [Comparative Functions of Apposition in M.M. Kotsiubynskyi’s Works], [v:] „Zapysky z ukrainskoho movoznavstva", vidp. red. O. I. Bondar, Odesa 2006, vyp. 16, s. 212-218. 
Matsko L.I., Sydorenko O.M., Matsko O. M., Stylistyka ukrainskoi movy [Stylistics of Ukrainian Language], za red. L. I. Matsko, Kyiv: Vyshcha shkola, 2003.

Mezhov O.H., Typolohiia minimalnykh semantyko-syntaksychnykh odynyts [Typology of Minimal Semantic and Syntactic Units], Lutsk: VNU im. Lesi Ukrainky, 2012.

Ostroushko O., Funktsii prykladkovykh konstruktsii u poetychnomu teksti (na materiali tvoriv L. Kostenko, I. Dracha) [Functions of Appositive Constructions in Poetical Text (on the material of L. Kostenko's and I. Drach's works)], [v:], ,Suchasni problemy movoznavstva ta literaturoznavstva", vidp. red. I. V. Sabadosh, Uzhhorod 2011, vyp. 16, s. 393-395.

Pidkaminna L.V., Apozytyvni epitety u poetychnii movotvorchosti T. H. Shevchenka [Appositive Epithets in T. H. Shevchenko's Poetical Style of Speech], [v:] „Naukovyi chasopys Natsionalnoho pedahohichnoho universytetu im. M. P. Drahomanova. Seriia 10: Problemy hramatyky i leksykolohii ukrainskoi movy", vidp. red. M. Ya. Pliushch, Kyiv 2007, vyp. 3, s. 241-246.

Sloboda N.V., Vidokremlennia yak zasib ekspresyvizatsii metafor (na materiali poezii shistdesiatnykiv) [Separation of Metaphors as a Means of Expressiveness (on the material of Sixtiers 's poetry)], [v:] „Naukovyi chasopys Natsionalnoho pedahohichnoho universytetu im. M. P. Drahomanova. Seriia 10: Problemy hramatyky i leksykolohii ukrainskoi movy”, vidp. red. M. Ya. Pliushch, Kyiv 2011, vyp. 7, s. 226-229.

Filiniuk V.A., Epitety-prykladky v poetychnii movi Emmy Andiievskoi [Appositive Epithets in Poetical Discourse of Amma Andiievska], [v:] „Naukovi zapysky Ternopilskoho natsionalnoho pedahohichnoho universytetu. Seriia: Movoznavstvo", hol. red. D. H. Buchko, Ternopil 2004, № 1 (11), s. 92-95.

Yatsuk O.V., Vyrazhalni zasoby realizatsii khudozhno-obraznoi funktsii napivpredykatyvnykh apozytyvnykh odynyts (na materiali ukrainskoi prozy kintsia XX-poch. XXI st.) [Realization of Artistically-shaped Function of Semi-predicative Appositive Units (on the material of Ukrainian prose at the end of XX-at the beginning of XXI centuries)], [v:] „Naukovi pratsi Kamianets-Podilskoho natsionalnoho universytetu im. Ivana Ohiienka. Filolohichni nauky”, vidp. red. L. M. Marchuk, Kamianets-Podilskyi 2012, vyp. 31, s. 193-199.

\section{Spysok vykorystanykh dzherel \\ [References]}

Andrukhovych Yu., Lysty v Ukrainu. Vybrani virshi [Letters to Ukraine. Selected Poems], [v:] Elektronnyi resurs: http://chtyvo.org.ua/authors/Andrukhovych/Lysty_v_Ukrainu_zbirka/ (20.12.2019).

„Bu-Ba-Bu” (Yurii Andrukhovych, Oleksandr Irvanets, Viktor Neborak): Vybrani tvory [, Bu-BaBu" (Yurii Andrukhovych, Oleksandr Irvanets, Viktor Neborak): Selected Works], uporiad. V. Gabor, Lviv: LA „Piramida”, 2008.

Vynnychuk Yu., Tango smerti [Death's Tango], [v:] Elektronnyi resurs: https://online-knigi.com/ page/190964 (28.12.2019).

Zabuzhko O., Druha sproba [Second Attempt], [v:] Elektronnyi resurs: http://poetyka.uazone. net/zabuzhko/ (28.12.2019). 
Izdryk Yu., Mertvyi shchodennyk [Dead Diary], [v:] Elektronnyi resurs: http://izdryk-y. livejournal.com/ (10.09.2018).

Lys V., Stolittia Yakova [Jakob’s Age], Kharkiv: Knyzhkovyi Klub „Klub Simeinoho Dozvillia”, 2010.

Matios M., Slodka Darusia [Sweet Darusia], Lviv: LA „PIRAMIDA”, 2011.

Symonenko V., Vybrani tvory [Selected Works], upor. A. Tkachenko, D. Tkachenko, Kyiv: „Smoloskyp”, 2012.

Shkliar V., Zalyshenets. Chornyi Voron [Remainer. Black Raven], Kharkiv: Knyzhkovyi Klub „Klub Simeinoho Dozvillia”, 2010.

Zhinoche kolo [Women's Circle], uklad. P. Horodyska, [v:] Elektronnyi resurs: http://shron1. chtyvo.org.ua/Horodyska_Polina/Zhinoche_kolo_zbirka.pdf (09.02.2020). 